\title{
UNITED NATIONS' CHANGING ROLE IN THE POST-COLD WAR ERA
}

\author{
DÍLEK LATİF
}

\section{ABSTRACT:}

This article analyzes the changing role of the United Nations in the post-Cold War era. After the end of the Cold War, many internal conflicts broke out in different parts of the world. There was a dramatic demand for the UN peacekeeping operations. Thus, the UN started to challenge traditional norms of international politics, such as state sovereignty, non-intervention into domestic affairs, and non-use of force in peacekeeping operations, and itself as an international organization. Within this context, this paper will examine the UN peacekeeping operations in the post-Cold War era; former Secretary General Boutros Ghali's "An Agenda for Peace"; case studies of Bosnia, Somalia, Rwanda, Haiti and Cambodia; blurring distinction between peacekeeping and peace enforcement; and humanitarian intervention of the UN. The article also seeks to analyze structural reform proposals for the UN to respond the challenges it faces today. Current issues of the Security Council reform proposals and financing the UN will be discussed.

\section{KEYWORDS:}

United Nations; Post-Cold War Era; Peacekeeping Operations; Structural Reforms. 


\section{Introduction}

Fifty-four years ago the United Nations was born out of the sufferings caused by the Second World War. The purpose of the Organization, as indicated in its Charter, was to save succeeding generations from the scourge of war. It aimed to correct the League of Nations' deficiencies, and managed to survive since 1945 , twice as long as the League of Nations.

In conformity with the Charter of the UN, the leadership of the UN in peace and security matters rests on the superpowers. However, emergence of the Cold War and its outcome in terms of bloc politics prevented the UN to perform its primary goal of the maintenance of peace and security. In the hostile environment of the Cold War, the UN could not play its role to implement the Charter provisions in many cases related to international peace and security. Though the Cold War prevented the UN to function satisfactorily in the peace and security matters, it nevertheless successfully pursued its Charter goals in many other areas such as decolonization, protection of human rights, respect for international law, promotion of social progress and better living standards for the people. In addition, to remedy the superpower rivalry the UN made some adjustments to cope with the threats to international peace and security.

Since the establishment of the UN, dramatic changes occurred in the world structure. The membership of the UN has increased sharply from 42 states to 185 states. The Third World members of the UN, using their majority in the General Assembly (GA) tried to shift the UN agenda from political and security matters to economical ones. Besides, the weight of the individual states on the world arena has changed, and new countries emerged with new roles in world affairs. In addition, the Organization, faced with different circumstances and challenges in different periods, tried to make adjustments and sought ways to overcome them. For example, to get rid of the paralyzing effect of the veto, regularly used by the superpowers against each other during the Cold War, the peacekeeping operations were invented. Likewise, the GA shared the responsibility of the Security Council (SC) against threats to international peace and security under the "Uniting for 
Peace" procedure. The aim of these innovations was to make the Organization in a way function even in the Cold War environment.

After the fading away of the Cold War, and the disintegration of the Soviet Union, there was a brief movement of hope and great expectations for the UN. It was believed that, at last the Organization could now start perform its original role as it was designed in the Charter. At that time, collective response to the Iraq's aggression against Kuwait strengthened the hopes for the future role of the UN in maintaining international peace and security. But, the Gulf War became the last case of the traditional kind of interstate conflicts in the post-Cold War era. On the contrary, many intra-state disputes, kept frozen during the Cold War, exploded. Moreover, with the end of the Gulf War, the UN's new kind of operations in the name of humanitarian intervention started. Consequently, there was a dramatic demand for the UN peacekeeping operations to respond to all kinds of conflicts taking place in different parts of the world. In response, the UN had to ungergo a remarkable renaissance in its efforts to deal world's problems since the end of the Cold War.

The scope of this article is thus to analyze the UN's changing role in the maintenance of international peace and security in the post-Cold War era. Within this scope, the UN collective security, peacekeeping and peace enforcement operations will be examined. Reform proposals to adapt the UN into the changing circumstances of the post-Cold War environment will be also analyzed. The main objective is to examine whether the UN has been successful in dealing with the challenges to international peace and security, and in conflict management in the post-Cold War era. This will be analyzed both in terms of conflict management and of structural reform.

\section{Historical Evolution of the United Nations}

As World War I led to the formation of the League of Nations, World War II led to the establishment of the United Nations. The victorious powers thought after World War I that there was a need for the League of Nations to institute a calming down period, so that states would not enter unwisely into destructive wars. Similarly, the winners of World War II believed that a stronger 
world organization was needed, one with a security council that had the authority to take binding decisions to oppose calculated aggression and cope with other threats to peace. In each case, the aim was to develop ways and means of maintaining peace and stability after a destructive world war.

The UN was established in 1945 and aimed to correct the League of Nations Covenant's deficiencies. The intention of the major powers in formulating the UN Charter was to remedy the fundamental weaknesses of the League such as the absence of effective collective security arrangements for the maintenance of international peace and security, and ultimate freedom of a member state to use force to effect a settlement.

Several deficiencies in the League's composition finally contributed to its failure. To sum up, the Covenant restricted the right to go to war but did not outlaw it. Recourse to war remained an option for the states. The most important great deficiency of the League was the power politics of that time. Although the big powers gave lip service to the idea of "Collective Security", in fact they practised balance of power. The assumption of universal membership could not be achieved since the US never joined to the League. The USSR was later expelled because of its invasion of Finland. Unanimity among all members was required for action, but members could reject to participate and leave if they choose. Moreover, the provisions for establishing the League were an integral part of the Treaty of Versailles, which excluded the axis powers and led them to alienation and sabotage.

As time passed, problems of the interwar period aggravated these obvious weaknesses. Members of the League re-established alliance systems and refused to take action against aggression. The League of Nations broke down and international community was driven to World War II although the formal dissolution of the League occurred in 1946. In 1946, the League of Nations dissolved itself; its assets, property and some of its functions were transferred to the UN. ${ }^{1}$

\footnotetext{
${ }^{1}$ Everyone's United Nations, New York: Department of Public Information Press, 1995, p. 5.
} 
However, World War-II co-operation among the Allied Powers did not continue for a long time. After the establishment of the UN in 1945, the world became divided ideologically into two camps, whose leaders the USSR and the US treated each other in total distrust and seemed to oppose each other on every major issue. ${ }^{2}$ The wartime bonds which brought the USSR, the US and Britain together against the German, Italian and Japanese aggression broken by the achievement of victory. As a result, conflict between the USA and the USSR after World War II prevented their cooperation for international peace and security, thus undermined the effectiveness of the UN.

The UN Charter's requirement for unanimity among the permanent members of the SC indicated the realities of power politics of World War II period. However, the Soviet Union's establishment of a Communist Bloc in Eastern Europe ended the big power co-operation, which post-World War II order had predicted, and rising disunity made SC operations extremely problematic. $^{3}$

In an attempt to understand how the UN of 1945 became the present UN, it is necessary to divide its last forty-four years during the Cold War into stages: Stage 1(1945-1960), Stage 2 (19601975), Stage 3 (1975-1989).

\section{Stage 1: 1945-1960}

In this period, the Cold War tensions between US-led West and the USSR-led East, made the most important intended change from the League of Nations impossible. The idea that the SC should be directed by the great powers failed because of the mistrust between the superpowers. In a world divided between two rival ideological blocs, power vacuums, economic and psychological warfare, a major arms race, and peripheral power contests, the UN was dominated by the US, its Western Allies, and

${ }^{2}$ Katherina Savage, The Story of the United Nations, New York: The Bodley Head Ltd. 1970, p. 11.

${ }^{3}$ Karen A. Mingst and Margaret P. Karens, The UN in the Post Cold War Era, Colorado: Westview Press, 1995 p. 29. 
Latin American followers. ${ }^{4}$ During this early Cold War period, the US mainly used the UN to contain the USSR.

In this environment, it was impossible to create the proposed UN machinery for the maintenance of international peace and security. Since East and West did not trust each other to carry dut military action on behalf of the UN, the SC activities became strictly limited. The Korean War was the most important example, which showed that the UN became an arena of ideological struggle between the two blocs. During the Korean War, the UN moved from being simply a forum for diplomatic pressure and propaganda to play a forceful role in a way not envisaged by the Charter. $^{5}$

The 1956 Suez Canal Crisis was another deviation from the Charter, different from the Korean War. Since British and French vetoes deadlocked SC action, the GA again used the "Uniting for Peace" procedure to discuss the Crisis. The majority of the General Assembly supported the idea that the British and French troops should be replaced by a UN force. Thus, United Nations Emergency Force (UNEF) in Suez became the first case of such military intervention of the Organization, deployed with the consent of Egypt and Israel. Peace-keeping operations had thus been invented for conflict management. It was a concept not found in the Charter, but came into usage from the special needs of the Cold War situation. Otherwise, UN would have been completely irrelevant to the maintenance of international peace and security because of the superpower competition and continvous veto.

While the Charter does not mention peacekeeping operations, specific measures to achieve the objectives of the Charter are set out in Chapters VI and VII. ${ }^{6}$ Chapter VI states that the member states have to settle their disputes by peaceful means without endangering international peace, security and justice. Under Chapter VII, the SC has to determine the existence of any threat to

\footnotetext{
${ }^{4}$ Saul H. Mendlovitz and Burns H. Weston, Preferred Futures for the United Nations, New York: Transnational Publishers Inc., 1995, p. 12.

5Ibid., p. 70.

${ }^{6}$ Qizhi He, "The Crucial Role of the UN in Maintaining Peace and Security" in The UN At Fifty, Christian Tomuschat (ed.), Hague: Kluwer Law Int., 1995, p. 84.
} 
the peace, breach of peace, or act of aggression and make recommendations, or decide what measures to be taken to maintain international peace and security. The Secretary General Dag Hammarskjold, during his tenure, called conception of peacekeeping "Chapter VI and a Half", and peace situated its identity midway between dispute settlement and peace enforcement. Thus it came to be considered as a bridge between the measures stipulated in the Chapters VI and VII of the Charter.

Peacekeeping operations have come to be defined as operations involving military personnel, but without enforcement powers, undertaken by the UN to help to maintain or restore international peace and security in areas of conflict. ${ }^{7}$ The objective in peace keeping operations is not to defeat an aggressor instead to prevent fighting, act as a buffer, keep order and maintain a ceasefire. Peace keeping forces cannot use force except in self-defense. They have to be neutral and impartial towards the adversaries. Furthermore, the peacekeepers must be present with the consent of the disputing parties, or at least the consent of one of them and the toleration of the other. ${ }^{8}$ When consent is withdrawn, the force must be removed. Otherwise, sovereignty of the states would be violated according to the original or as it became "traditional peace keeping" operations.

However, the UN operation in Congo from 1960 to 1964 illustrated the way in which the Cold War continued to dominate the UN in the security field. At the same time, it showed the limits of the peacekeeping operations. Although a unified Congo was left after four years of intervention, and some observers viewed this as an important achievement, it was clear that the UN lost its neutrality and impartiality in defusing the crisis. ${ }^{9}$

During the first stage of UN, all the UN members, especially the superpowers, tried to use the organization to further their national interests. The USA was the most successful, because of its

${ }^{7}$ Edward Moxon Browne, A Future for Peace Keeping, New York: St Martin Press Inc., 1988, p. 2.

${ }^{8}$ A. LeRoy Bennett, International Organizations Principles and Issues, New Jersey: Prentice-Hall Inc., 1991, p. 104.

${ }^{9}$ Thomas G. Weiss, David P. Forsythe and Roger A. Coate, The UN and Changing World Politics, Colorado: Westview Press Inc., 1994, p. 46. 
dominance in international society. The UN was controlled politically and financially by the US and its allies more strictly in the first stage compared to UN's whole history. The superpower rivalry prevented the creation of the intended security machinery and reminded that the UN depended on the attitude of its members and the international climate. But this did not prevent the UN from playing a useful role in some disputes and the development of peacekeeping role, which sometimes helped to enhance world peace. ${ }^{10}$

\section{Stage 2: 1960s-1970s}

Two characteristics stood out in these decades. In 1960s, the UN provided assistance to decolonization in Africa and Asia and the decolonization transformed the UN into a Third World dominated organization, in which the US dominance declined when it lost two-thirds majority in the GA. This has changed the former balance between the GA and the SC. In consequence, the UN agenda widened and economical and developmental issues, directly related with the Third World, proliferated. This helped the two superpowers to defuse their distrustand continue to exist peacefully in a détente environment.

The new third world members of the UN were not entitled to permanent membership in the SC. Therefore, they focused on GA for helping to define the UN's commitment to social progress and higher standards of living. Hence, there were many yearly conferences on development and related issues. Besides, the USSR, leader of the Eastern Bloc was taking the side of the Third World.

It was also during this period that, largely as a consequence of decolonization, the previously tight bipolar world loosened via a non-aligned movement headed by China, Egypt, India, Indonesia, and Yugoslavia. ${ }^{11}$ They tried to force the UN to join their efforts against the domination of the US, the USSR or sometimes both of them. As the non-aligned movement grew, most of the newly independent states did not see the Cold War as their main problem.

\footnotetext{
${ }^{10}$ David Amsrtrons, Lorna Loyd and John Redmond, From Versailles to Maastricht, London: Mc Millan Press, 1996, p. 87.

${ }^{11}$ Mendlovitz/Weston, Preferred Futures, p. 13.
} 
They had their main own agenda, which concentrated on mainly development issues, anti-colonialism and racid discrimination. They also wanted to change the UN into a more democratic organization. So, in this period ECOSOC (Economic and Social Council) became more representative and pronovaced within the UN structure. Its members grew from 18 to 27 in 1965 and then to 54 in 1973. The Security Council also expanded from 11 to 15 in 1965.

However, efforts of the non-aligned movement were not strong enough to prevent the Vietnam War, which took place toward the end of this era. ${ }^{12}$ Over Vietnam, the UN was quite helpless. It could not solve the conflict. Since the Soviets supported the Communist Vietnamese, and Americans were fighting with them, the SC could do nothing. The GA could not do anything adequate as well. China and North Vietnam, who were not the UN members at that time, ignored any recommendation it made. The failure of UN in the Vietnam War was another event that led to loose of faith in the UN and its future in the eyes of many people.

However, while the UN could do nothing when the superpowers were involved, otherwise its peacekeeping activities continued to make a valuable contribution to peace with the support not just of the major powers but also of the third world states. For example, the UN force in Cyprus (UNFICYP) was sent in 1964 to try to prevent fighting between Greek and Turkish Cypriots and to maintain order. During its ten years of presence, UNFICYP provided humanitarian assistance, act as a buffer between the communities and tried to keep relations calm and diffuse the iner-communal tension.

At the second stage, international society transformed with the emergence of third world countries. The main impact of the Third World was in shifting the UN's priorities and altering the international agenda by revolting colonializm, racial discrimination, and the North-South gap. While the GA started to be more active the SC could still not play the, leading role in most of the international disputes because of the Cold War.

${ }^{12}$ Ibid., p. 12. 
This stage was characterised with the end of US dominance in the UN because of the changes in membership. The US and its allies lost the two-thirds majority, necessary for the passage of important resolutions. ${ }^{13}$ Before the decolonialization, the US had commanded two-thirds majority in the GA easily. However, during the period under consideration, she had to make compromises to third world countries for building coalitions against the USSR. Therefore, it was in this period that the US started to reduce its contribution to the UN budget.

\section{Stage 3: 1980s}

By 1980 s, the slump of previous decades was turning into crisis. There was a total frustration of hopes and disillusionment both among developing and developed countries as to the UN's role in world politics. The UN was unable to play the central role in many conflicts in this period. For example, the revolutionary Iranian government, came to power in 1979, ignored appeals from the SC to release the American diplomatic hostages. Fighting between China and Vietnam was still continuing. In December 1979, the Cold War flared up when the USSR invaded Afghanistan. Then, Iran-Iraq war began in September 1980, and the SC idly watched two 'troublesome' states slaughtering each other. ${ }^{14}$ Moreover, during the 1980s, the UN's long-standing financial difficulties became acute, which was exacerbated by the reduction of the US's contribution to its budget.

Despite all these negative developments, there was one positive thing, which refreshed hopes for the UN once again. It was the outcome of peaceful existence of détente between the two superpowers. Starting from the mid-1970s, relations between the US and the USSR became friendlier. However, cordial relations between them were again suspended when the USSR invaded Afghanistan. Thus, nearly all the old obstacles that prevented the UN's actions remained. During the period there were many international conflicts in the form of civil wars, guerrilla wars, armed rebellions that the UN could not intervene. Thus the UN was

\footnotetext{
${ }^{13}$ John G. Stoessinger, The UN and the Superpowers, New York: Random House Inc., 1965, p. 7.

${ }^{14}$ Amsrtrons/Loyd/Redmond, From Versailles to Maastricht, p. 113.
} 
quite helpless in Northern Ireland, against the Kurdish groups and the mujahadeen in Iran, Peshmerga Kurds in Iraq, the guerrilla war in Malesia, the civil war in Chad, Sudan, Colombia, Salvador, and Nicaragua. ${ }^{15}$

The UN was disabled to play any role in these internal conflicts because of the unwillingness of the disputants. At the same time, the Organization did not call into question the prohibition contained in Article 2(7), which is the principle of nonintervention into domestic affairs. This demonstrated the UN's impotence to adapt changing circumstances and dealt with new kind of conflicts it faces.

The most striking feature of the UN efforts to deal with threats to international peace and security in the late 1980s was newly emerging co-operation among the five permanent members of the SC. One indication of this was that the decisions were started to be taken in unofficial and informal way through the consultations of SC's permanent members. Another indication was voting patterns in the Council. Between 1980 and 1985, permanent members voted together in 75 out of 119 resolutions, and between 1986 to 1990 , they voted together on 93 out of 103 resolutions. ${ }^{16}$ Thus, revival of the SC was under way.

However, the most significant sign of the co-operation was the SC resolution of 1987 for ending Iran-Iraq war. Then, in 1988 the USSR under the leadership of Gorbachev decided to solve the Afghan conflict, which had refreshed the Cold War in 1979. Most important factor contributing to these developments was the changes in the Soviet foreign policy. Under the leadership of Mikhael Gorbachev, the USSR improved relations with the USA and China and turned to the UN for searching a new role in the world politics.

The end of the Cold War also made possible the removal of one of the longest troubles the UN had faced. Two agreements were signed to end fighting in south-western Africa. The first agreement was signed by Cuba, Angola and South Africa. This

\footnotetext{
${ }^{15}$ Maurice Bertrand, The UN Past, Present and Future, Hauge: Kluwer Law Int. Inc., 1997, p. 59.

${ }^{16}$ Ibid., p. 83.
} 
contained a plan for achieving the independence of Namibia, the ex-German colony of south-west Africa that was seized by the South Africans during the First World War. ${ }^{17}$ This plan provided a UN force for guaranteeing necessary conditions for free and fair elections. The second agreement provided withdrawal of Cuban troops from Angola. By linking Namibian independence with the withdrawal of Soviet sponsored Cuban troops in Angola, a December 1988 agreement to send peacekeepers to both territories removed another source of Cold War tension. ${ }^{18}$

The UN made a great contribution for the success of these agreements. It played an important role by supplying the framework within which main part of the settlement had been negotiated ten years before the agreements was signed. Permanent members of the SC, the US and the USSR accepted to be guarantors for the implementation of the agreements. In short, as in the Afghanistan negotiations, so in the Angola/Namibia, talks, the impression was strongly conveyed that any party seeking to undermine a settlement would incur the disfavour of both superpowers. This increased the confidence of each side that the other side would keep their promises and enhanced the UN contribution to the resolution of conflicts.

In conclusion, the UN, like the League of Nations, has largely failed to perform its role for the maintenance of the international peace and security during the Cold War. It remained out of the most important problems and events, despite the efforts of the Secretary-Generals, diplomats of the SC and the GA. The SC deadlocked and could not perform its function because of the Super Powers' veto to stop the resolutions against their national interests.

Although the UN dominated by the US and its Western allies during the early Cold War period, this situation started to change with the decolonization process in the 1960s. This altered the previous balance between the GA and the SC, and so transformed the UN into a third world dominated organization. However, the UN was not able to materialize the demands from both the First and Third World countries. While the complaints of the developing

${ }^{17}$ G. R. Berridge, Return to the UN, London: MacMillan, 1991 p. 71.

${ }^{18} \mathrm{Amsrtrons} / L o y d /$ Redmond, From Versailles to Maastricht, p. 123. 
countries grew due to the deterioration of the economic conditions, developed ones' dissatisfaction was increasing as well because of the Third World domination in setting the UN agenda. Thus, 1980s started with the frustration of hopes and disappointments for the UN's future role in the world.

However, in all these different periods peacekeeping operations of the UN were useful in conflict management. Even though the UN in the Cold War era did not achieve the ambitious aims of its founders to remove the scourge of war, at least it made a progress toward that goal. ${ }^{19}$ When the SC could not function because of the super power rivalry, it still worked to contain or end wars in many parts of the world by establishing peacekeeping operations. Most of these wars, which had a danger of escalation, stopped by this way.

Moreover, failures to settle all conflicts were not the fault of the UN, which was used by its members as a means to achieve their goals. In fact, the UN had been an instrument for its members, particularly for the super powers. It achieved consensus on the questions which were not important or which the international community wanted to get rid of. The major reason for the UN's failure was the opposition between the US and the USSR, which led to a deadlock in the SC. However, structure of the organization with an undemocratic SC, heavy bureaucracy in the Secretariat, and no military staff- was also effective to prevent it from being a useful instrument in solving disputes.

\section{Redefining the UN's Role in Conflict Management UN After the Cold War}

In the late 1980s and early 1990s, the international arena saw a considerably changed environment. The dissolution of the USSR and the Soviet bloc reduced the suspicion and the hostility between the two blocs, which represented by the two superpowers during the Cold War. This gave momentum to the UN's role in the field of international peace and security.

${ }^{19}$ Amos Yoder, Evolution of the UN System, Washington: Taylor and Francis Pub., 1993, p. 96. 
Furthermore, the disappearance of the old hostilities created a more comfortable environment in the SC. There was a new willingness among the permanent members to co-operate for dealing with the crises, and carrying out their primary responsibility for the maintenance of international peace and security. ${ }^{20}$ With Gorbachev's initiative to end the Afghan war, a new era of co-operation began in the UN SC. The right of veto that was used by each side to block decisions in the past was left aside. There was substantive consultations between the US and the Russian Federation, and to reach a consensus in the decisionmaking process became easier. It was the time of rising expectations for the UN. There was an illusion that the UN would be used as an effective instrument for solving disputes, which was consolidated by the success of the UN coalition in defeating Saddam's attack on Kuwait.

Moreover, there was a renewed hope among the politicians and scholars that finally unanimity would be realized in the SC. It was thought that, the UN was going to perform its primary role as indicated in the Charter, which is the maintenance of peace and order in the world. At that time, the Gulf War was seen as the first test case to show the new willingness among the super powers to co-operate for the maintenance of the world peace and stop the aggressor states through collective security. In this mood UN almost universally condemned Iraq's invasion of Kuwait in 1991, and imposed economic sanctions.

\section{Gulf War}

On August 2, 1990, Iraqi armed forces swept past the border of neighboring Kuwait and quickly gained control of this tiny, oilrich country. SC immediately demanded from Iraq to withdraw or face with force of collective response. When Iraq ignored the warnings, the UN Resolution 678 demanded Iraq to comply with previous UN resolutions asking its withdrawal, and authorized member states to co-operate with Kuwait using "all necessary means" to restore peace to the area. Consequently, Operation Desert Storm began on 17 January and ended in March 1991.

${ }^{20}$ Qizhi He, The Crucial Role of the UN, p. 85. 
However, the military operation against Iraq did not qualify as a "Collective Security" action for many people. Although the US-led coalition was supposed to act on behalf of the UN, unlike the Korean situation in the early 1950s, UN flags and symbols were not used in the military action. As in Korea, the SC was not be able to control the US and the coalition, and failed to perform its supervisory role. The war's objectives far exceeded the mandated mission to restore Kuwaiti sovereignty, and the military action of the coalition force generated new security and legal problems. ${ }^{21}$ The use of force to destroy the civilian infrastructure of Iraq, continuation of fire against Iraqi troops withdrawing from Kuwait and breakdown of Iraq's internal order were regarded as some of the abuses of the US-led coalition. Even, there was a criticism that the UN hastily started the operation as a result of the US pressure without exhausting all the non-military measures.

However, after the victory of the UN coalition against Iraq, the UN shared the success and increased its prestige. The US-led military action in the Gulf regarded as an example of stronger UN after the Cold War. But it was also greeted with suspicion. The operation's lack of direct link to the UN made most of the members to have no say in the operation. For example, Germany and Japan, who were expected to contribute monetary resources for the collective action, were excluded from important decisionmaking meetings, which in turn, fuelled their interest in permanent membership in the SC. ${ }^{22}$ After all, the Gulf War left a positive image in the minds of people and increased demands for the deployment of the UN peacekeeping operations.

\section{Post Gulf War Experience}

The Gulf War was also important for showing that the UN for the first time needed to deal with the humanitarian aspects of a conflict. After Iraqi forces withdrew from Kuwait, the UN, in response Iraq's pressure on the Kurdish and Shiite populations within its borders, undertook a humanitarian intervention and provision of a "safe haven" for refugees. The SC condemned Iraqi

${ }^{21}$ Tareq Ismael and Jacqueline S. Ismael, The Gulf War and New World Order, New York: University Press of Florida, 1994, p. 35.

${ }^{22}$ Mingst/Karens, The UN in the Post Cold War Era, p. 89. 
repression as a threat to international peace and security, and authorized humanitarian organizations to offer assistance. As a result, the US and other western states (Britain, France, Netherlands, Spain, Italy and Germany) created refugee havens in northern Iraq for the Kurds under Operation Provide Comfort. By this way, the UN linked humanitarian and security issues. At the same time, developing states, though they were supporting the action, worried about the decisions that brought UN interference in states' internal affairs and diminishing sovereignty when the UN helped Kurdish refugees in northern Iraq under the justification of humanitarianism.

However, the Gulf War became the last case of the traditional kind of inter state conflicts. On the contrary, many intra-state disputes, which took the form of ethnic conflicts and civil wars, broke up in different parts of the world, in the post-Gulf War period. The end of the Cold War contributed to the resurgence of nationalism and ethnic conflicts, especially in the regions formerly under authoritarian and communist regimes. It is closely linked to the disappearance of the Cold War tensions from the East-West rivalry that froze long-standing regional and internal conflicts as well. This resulted in new demands for self-determination, and a new generation of civil wars such as in Yugoslavia, Georgia, Armenia, and Azerbaijan. Likewise, a new phenomenon of "failed states" in Africa emerged in international politics. More than a decade of economic decay, devastating state policies, corruption, natural disasters, and civil wars led to the collapse of law in Zaire, Somalia, and Rwanda.

As a consequence, there was a dramatic demand for the UN to respond to all these conflicts, and military operations of the UN increased enormously. Since the conclusion of the Gulf War, the UN has launched fourteen new operations in Angola, Somalia, Mozambique, Georgia, Liberia, Rwanda, Haiti, and South Africa. However, those operations are qualitatively and quantitatively different from the earlier UN peacekeeping operations during the Cold War. ${ }^{23}$ New kind of conflicts were within states rather than between them, and problems were arising from weak institutions, secessionism, ethnic and tribal clashes and civil wars.

${ }^{23}$ Weiss/Forsythe/Coat, The UN and Changing World Politics , p. 74. 
Such kind of conflicts led to the questioning of the longstanding principles of state sovereignty and non-intervention in states' domestic affairs. Apart from this, a new debate emerged whether the internal conflicts of the post-Gulf period gave the signals of the new role for the UN. All these opened up a new era in international politics and brought about novel concepts such as humanitarian intervention and eroding sovereignty. Under these conditions, the UN called on to deal with new kinds of armed conflicts, which could not be predicted when the UN Charter was drafted. Instances of cross-border attacks from national armies aimed at annexation of another state's territory become rare, and interstate conflict replaced by intrastate conflict as a main threat to international peace and security. Raised from ethnic, economic, and nationalist desires for autonomy inside state borders, civil war has recently became the most common form of armed conflict. And the UN proved unable o cope with all this new problems.

Actually, the UN Charter provisions for dealing with threats to international peace and security were designed for interstate conflicts not intrastate or civil wars. For this reason, the organization was ill equipped to deal with conflicts within internal borders. The new kind of conflicts resulted too in a change in the scope of the peacekeeping operations. Blue Helmets started to face many problems such as disarming of fractions, the return of refugees, temporary civillian administration, assisting humanitarian relief, and the organization and supervision of elections.

Although the UN operations since the end of Cold War had an advantage over their predecessors -the unanimous support of the SC members- they could not be successful. It seemed that the UN has to improve its capabilities to overcome its deficiencies in handling these conflicts. Clearly, the UN had to reform itself to meet new demands and to provide greater capacity in managing conflicts.

\section{Reform Proposals for Adapting and Enhancing the UN Peacekeeping Operations}

The growing demand for the UN peacekeeping operations and the range of new tasks entrusted to multinational military forces in recent years have presented both the UN and troop- 
contributing countries with major operational and management challenges. ${ }^{24}$ Failure of UN missions after the Cold War led to reexamination of the basic principles and practices of peacekeeping as a basis for initiating and conducting operations. Hence, the UN accelerated its search to improve its capacity in conflict resolution.

The emergence of co-operative spirit among its permanent members motivated the SC meeting on 31 January 1992, for the first time at the level of heads of states and governments. The members of the Council stressed the importance of strengthening and improving the UN to increase its effectiveness. At the end of the meeting, the SC adopted a declaration, which called on the Secretary General to recommend ways to improve the UN capacity for preventive diplomacy, peacekeeping and peace making. ${ }^{25}$

On June 1992, the Secretary General submitted to the member states a report presenting integrated proposals for more effective UN activities. In the report, titled as "An Agenda for Peace", Secretary General Boutros Boutros Ghali examined the changing context of international relations and searched for ways to improve the Organization's capacity for international peace and security. Although the document emphasized new dimensions of security and an expanded UN role in the realm of international peace and security, it also reconfirmed the sovereign state as the fundamental actor of the international politics and did not go as far to challenge the principle of non-intervention. ${ }^{26}$

An Agenda for Peace distinguished four broad categories of UN activities on behalf of peace: Preventive Diplomacy, Peacemaking, Peace Building and Peacekeeping. The report attempted to develop a new strategy for maintaining peace and security on these four fronts. Each of these stages was defined with various goals. Specific proposals were made for new UN roles and new UN methods. B. Boutros Ghali recommended the increased use of confidence building and fact-finding activities as well as the

${ }^{24}$ Mats R. Berdal, 'Wither UN PeaceKeeping', Adelphi Paper 281, October 1993, p. 26.

${ }^{25}$ Dimitris Bourantis and Jarrod Wienner, The UN in the New World Order, London: MacMillan Press, 1995, p. 13.

${ }^{26}$ Keith Krause and W. Andy Knight, State Society and the UN System, Tokyo: UN University Press, 1995, p. 15. 
establishment of an early-warning system for assessing possible threats to peace to promote preventive diplomacy.

Preventive Diplomacy seeks to resolve disputes before violence breaks out. Main objective of the preventive diplomacy, which was invented to overcome the ambiguity and vagueness of the newly appeared conflicts, is to ease tensions before they end in conflict. It was supported by the member states without reservation.

Peacemaking requires use of the same diplomatic skills as the preventive diplomacy. The aim is to reduce the intensity of the conflict through negotiation, as a step on the path to a cease-fire. The responsibility here is to bring hostile parties to an agreement by peaceful means. However, those idealistic phrases may not properly work in practice. It was possible to be highly critical of the peacemaking process in the former Yugoslavia, which in a way set a grave precedent by allowing frontiers to be changed by force. It should be noted that while impartiality is important in humanitarian efforts, it is not always correct in mediation efforts where principles of international law and norms must be maintained.

Peace Building, as described in the report, requires strengthening the institutions to consolidate a sense of confidence and well being between people. ${ }^{27}$ This final category of operation involves the building of all sorts of "structures" (such as social services, a judiciary and responsive government) that strengthen peace and order. ${ }^{28}$ Peace building can occur before or after a conflict, but is certain to be badly needed in the aftermath of war. In the aftermath of international war, post conflict peace building may take the form of concrete co-operative projects which link two or more countries in a mutually beneficial undertaking that can not only contribute to economic and social development, but also enhance the confidence that is so fundamental to peace.

Peacekeeping transformed rapidly after the end of Cold War. Quantitatively, peacekeeping has attained a new magnitude.

${ }^{27}$ Boutros Boutros Ghali, An Agenda for Peace, A/47/277-S/24111, [http://www.un.org/plweb-cgi/idoc.pl.], 17 June 1992, p. 12.

${ }^{28}$ Eric Fawcet and Henna Newcombe, United Nations Reform, Toronto: Science for Peace, 1995, p. 125. 
Qualitatively, the peacekeepers confront previously unknown issues of policy and practice. It had to deal with novel aspects of humanitarian affairs and be comprehensive. After the end of the Cold War, the UN was expected to authorize personnel to implement cease-fires; demobilize regular and irregular military forces; inspect arms control constrains; observe troop withdrawals; train and oversee police forces; provide administrative oversight of government ministries; plan, administer and monitor elections; watch for human rights violations; provide safe havens for displaced persons; and protect personnel attempting to give humanitarian assistance in war-torn areas. ${ }^{29}$ Consequently, a mixture of classic peacekeeping operations and new enforcement tasks has emerged. Therefore, the aim of the "Agenda for Peace" in producing the concepts of preventive diplomacy, peace making and peace building was to support the peacekeeping operations.

It was learned from the new kind of peacekeeping operations of the UN that for peacekeeping to succeed like peacemaking, the parties to a conflict must have the necessary political will. Peacekeeping even more than peacemaking, requires the adherence of the conflicting parties to the principle of peaceful resolution of conflicts, in other words, to the Charter itself. ${ }^{30}$ The world community needs better-prepared forces to use as UN peacekeeping personel in additional places, which is different from the traditional form. It needs a plan for a prudent extension of operations in the domain of enforcement under Chapter VII of the Charter. Agenda for Peace further mentioned the need for military support of the new kind of operations. This opens the way to enforcement element within peacekeeping operations by abandoning the long-standing distinction between enforcement and peacekeeping.

To this list "peace enforcement" was added later to refer to enforcement measures taken by the UN to restore peace, under the provisions of Chapter VII of the Charter. It involves peacekeeping activities, which do not necessarily involve the consent of all parties concerned. What differentiates peacekeeping from peace

${ }^{29}$ Mendlovitz/Weston, Preferred Futures for the United Nations, p. 167.

${ }^{30}$ Boutros Boutros Ghali, Report on the Work of the Organization, New York: Department of Public Inf., September 1993, p. 101. 
enforcement is the level of violence and intensity of activity. ${ }^{31}$ Increasingly the distinction between the two concepts has been blurred after the end of the Cold War. Facing with the changing nature of the conflicts, where everything was in complete disorder, there was an intense use of violence among the multiple parties of the conflict and where there was no willingness to end the conflicts and cease-fire agreements are not respected, the UN's Blue Helmets obliged to use force.

Moreover, the UN SC decision to use force to make humanitarian aid available in Somalia has provoked a great debate. The SC's practice on Somalia caused confusion between traditional Chapter VI-based peacekeeping and military enforcement based on Chapter VII of the UN Charter. In fact, nothing is more dangerous for a peacekeeping operation than to ask it to use force when its existing composition, armament, logistic support and deployment deny the capacity to do so. ${ }^{32}$ The logic of peacekeeping flows from political and military premises that are quite distinct from those of enforcement; and the dynamics of the latter are incompatible with the political process that peacekeeping is intended to facilitate.

Ethnic conflicts blur the line between domestic and international, state and non-state actors, as well as that between Chapter VI and VII. They have also changed the doctrine that only interstate conflicts can be a threat to international peace and security (Article 39). Such conflicts, where huge number of people get killed, forced to seek refuge and created a danger for neighbouring countries, has became for many peace-keepers and experts a threat to international peace and security. They advocated an arguement that it would be wise to include a new Chapter into the Charter, dealing with the ways and forces to end similar conflicts with special operations.

However, there was a general consensus after Bosnia and Somalia that limited enforcement actions proved contradictory and

31 J. Taylor Wentges, 'Force Function and Phrase: Three Dimensions of UN Peacekeeping', International Peacekeeping, Vol. 5, No. 3, Autumn 1998, p. 61.

32 Boutros Boutros Ghali, Supplement to An Agenda for Peace, A/50/60S/1995/1, [http:www.un.org/pweb-cgi/idoc.pl], 3 January 1995, p. 8. 
ineffective and peacekeeping commanders should use force only as a last resort. Hence, the organization has come to realize that a mix of peacekeeping and enforcement is not the answer to a lack of consent and co-operation by the parties to the conflict. Nevertheless, where the SC authorizes the use of force even to limited extend, under Chapter VII of the Charter, the composition, equipment and logistic support of such an operation must be commensurate with the task.

In addition, in "An Agenda for Peace", the former Secretary General Boutros B. Ghali made several references to collective security. He explained that:

An opportunity has been regained to achieve the great objectives of the Charter - a UN capable of maintaining international peace and security of securing justice and human rights and of promoting, in the words of the Charter, 'social progress and better standards of life in larger freedom'. This opportunity must not be squandered. The Organization must never again be crippled as it was in the era that has now passed.

The Secretary General's Agenda for Peace was widely recognized as a starting point for serious discussion on how to revitalize the collective security system envisaged in the UN system. Since it is not possible to determine an aggressor state in the changing nature of conflict, future of the collective security is under debate.

The idea of collective security expands the principle of "one for all and all for one" to the global level. It is the system that all states thwart an aggressor state by joining together against it, first by preventing the outbreak of force and then by meeting aggression with force. However, the collective security system could not be realized during the Cold War, as its developers expected. One of the primary reasons was the use of the veto by both the US and the USSR, each seeking to prevent SC action advocated by the other. Another reason was that the world politics often made it impossible to act collectively, and states chose to disobey or ignore the prohibitions and restrictions on the use of force to pursue national interests. Collective security was not an appropriate system to operate during Cold War which was marked by East-West rivalry. Thus, in place of collective security, the UN 
developed alternate means to cope with conflicts under peacekeeping.

The end of the Cold War gave way to a new spirit of cooperation in the UN's SC. Collective response to the Iraq during the Gulf conflict strengthened the optimistic views of the organization. However, the Gulf War became the last example of interstate conflict. Since the Gulf War, the UN faced with many internal conflicts. The mechanism of the UN, the norms and the rules of the Charter provided the framework for action against Iraq. However, different circumstances in the internal wars, where determining an aggressor state was impossible, caused to question the relevance of the conceptions of the collective security. The collective security system lacks norms and rules for involvement in interstate crises. The unpredictable challenges posed by the new international order require both new norms and more effective means for managing the new kind of conflicts.

Boutros Ghali in his Agenda for Peace also recommended the establishment of a rapid deployment "peace enforcement units" on a permanent basis under the command of the Secretary General.

To sum up, the UN indicated concern for addressing the newly emerging issues, but many questions remained unanswered. The "Agenda for Peace" report by the Secretary General Boutros Ghali addressed several strategies that were both old and new. Peacekeeping, a traditional activity for the UN, received theoretical reinforcement from enhanced proposals for peace making and preventive diplomacy. Even with these approaches, however, the report adopted much of the state centric image that accompanied the formation of the UN. By failing to recognize the fact that the states were not anymore the sole participants in the intentional system of peace and war, the report missed the opportunity to address the new options. In addition, it failed to develop the concept of "preventive diplomacy" in ways that offer adequate promise for serving the critical early warning functions necessary for UN effectiveness. Beside, establishment of permanent UN forces were not acceptable for the member states because they afraid of that one day these forces may be used against them or beyond their control. They also showed the same unwillingness in paying their shares to the UN budget. 
The Agenda for Peace report, however, has sparked significant debate on important and relevant issues. Unless member states come to understand the changes in the nature of the international system and of the types of the participants active in the system, they will continue to respond with irrelevant remedies to increasingly serious international diseases.

Although the UN after the Cold War expected to perform its role as indicated in the Charter, it could not be successful. Efforts of the Secretary Generals, SC and the GA resolutions, even comprehensive reports such as An Agenda for Peace, which aimed to adopt the UN's mechanism to the changing circumstances, could not save it from failing. Most of the proposed solutions to cope with internal wars in the post-Cold War era could not produce the expected outcomes. Even though the UN played a role in many of these wars, it still faced challenges from different angles.

We will focus below on five major conflicts after Cold War that presented specfic challenges to the UN to clarify the UN's successes and failures, changing conceptions, and the new tasks that it have to perform: Yugoslavia, Somalia, Burundi and Rwanda, Haiti and Cambodia. The first three of these conflicts in Yugoslavia, Somalia and Brundi/Rwanda exemplifies changing conditions for enforcement and humanitarian intervention. The other two conflicts in Haiti and Cambodia illustrate other features of these new peacekeeping operations, which are peace building and election monitoring. The UN's intervention was relatively more successful in establishing a stable government in Haiti and Cambodia than the first three operations.

\section{Case Studies}

\section{The Way in Former Yugoslavia}

The UN involvement in Yugoslavia began with the SC Resolution, which adopted a general and complete embargo on all deliveries of weapons and military equipment to Yugoslavia. ${ }^{33}$ The

${ }^{33}$ Geoff Simons, UN Malaise: Power, Problems and Realpolitik, New York: St. Martin Press, 1995, p. 82. 
issues raised in Yugoslavia go to the heart of the nature of international order and international law in the post-Cold War era, touching questions of self-determination, individual and group rights, and the exercise of limits of sovereignty. Thus, the UN hesitated whether to intervene or not for a while. Then, Security Council accepted the SC proposals for a peacekeeping operation and the UN protection force (UNPROFOR) established in 1992.

Throughout the conflict the impression grew that the UN was largely impotent. Divisions among the SC's members created unproductive means to resolve the conflict. Despite SC authorization, the reluctance of governments and their militaries to use force more extensively demonstrated the limitations of the UN's enforcement role, except in cases where strong national interests are at stake, as in the Gulf War. Therefore, after Yugoslavian tragedy, it was seen that international community was reluctant to intervene into conflicts, which were not threatening global stability. Many people were killed for ethnic reasons. While the UN resolutions were ignored, its peacekeepers were attacked and there was a general lack of support for UN efforts by the US and others. On the other hand, the UN efforts such as economic sanctions and peacekeeping at least prevented the conflict from spreading to its neighbours, and the humanitarian assistance was useful to some extent that provided the framework for the final peace-negotiations and agreement.

\section{Somalia}

In 1991 and 1992 civil order collapsed in Somalia when warring clans took control over parts of the country. ${ }^{34}$ Deaths, scarcity of food and famine accompanied the fighting and forced thousands of people to seek emergency humanitarian assistance. A small mission formed by Pakistani troops was sent to Somalia (UNISOM I) to protect humanitarian relief workers. Then, SC Resolution 794 authorized a large US led military-humanitarian intervention (Unified Task Force on Somalia, or UNITAF, also

\footnotetext{
${ }^{34}$ For more information look at Michael G. Schechter, "The UN in the Aftermath of Somalia", in Edwin M. Smith (ed.), The UN in a New World Order, California: Keck Center for International and Strategic Studies, 1994.
} 
known as Operation Restore Hope) to secure ports and airfields, protect relief shipments and workers, and assist humanitarian relief efforts. However, the mission's scope was ambivalent. The US did not intend to commit its forces for a long period and the objective was limited to humanitarian issues. When the UNISOM I failed to safeguard the delivery of humanitarian assistance, UNISOM II went in 1993 and realized a large-scale humanitarian work. Nevertheless, the useful job done by the UN was countered with the loss of impartiality by it in supporting the elimination of General Aidid. Departure from neutrality led to the negative image of UN operation and gave impetus to the strife. By the time, the situation deteriorated and the UN's soldicrs faced with force. Therefore, in Vctober 1994, while the parties in Somalia showed unwillingness to reconcile with each other, it was felt that Somalis lost their chance and then the force withdrawn in January 1995. Soon afterward, General Aidid was killed and fighting among clans again spoiled stability in Somalia.

The Somalia operation was not similar to the proceeding ones. It took place in a state where there was no order, no government authority, and so the concept of sovereignty lost its meaning. During the operation, UN violated one of its principles; states in conflicts should request UN to intervene. It also showed institutional weaknesses and impotence of the leadership of the UN in cases where the maintenance of impartiality is difficult.

\section{Burundi and Rwanda}

Internal and cross-border conflict broke out in Rwanda in October 1990, with sporadic fighting between the armed forces of the Hutu-led government of Rwanda and the Tutsi-led Rwandan Patriotic Front (RPF) operating from Uganda. ${ }^{35}$ In 1993, the Rwandan government and the RPF reached a cease-fire agreement. Later, they called on the SC to install UN military observers to their common border for preventing military use and transport of military equipment on the borders. In 1993, SC established the UN Observer Mission Uganda-Rwanda (UNOMUR).

35 Basic Facts About the UN, New York: Department of Public Information Press, 1995, p. 46. 
Then, UN representatives tried to help in negotiations for a new government and a cease-fire. The peace was concluded successfully, however, the local massacres did not end. After many people have been killed and millions of Rwandan refugees escaped to neighbouring countries, the SC decided to set up another international force; the UNAMIR (the UN Assistance Mission for Rwanda), for the implementation of the peace agreement. UNAMIR concentrated on arranging a cease-fire, but it was not successful and killings continued. Thus, the SC considered the situation in Rwanda as a threat to international peace and security, and imposed an arms embargo against Rwanda. Then, the Council authorized, under Chapter 7 of the UN Charter, a temporary multinational humanitarian operation. The civil war ended after RPF forces took control in Rwanda; they declared a cease-fire and a transitional government was established for five years.

As UN Secretary-General Boutros Ghali expressed in his speeches, the UN operation in Rwanda was not only ended with a failure for UN, but also for the international community. It became increasingly clear that even the new UN initiative, the relatively modest proposal that the perpetrators of genocide should be brought to justice, was doomed to failure because of lack of resources, incompetence, and the indifference operation of powerful states. ${ }^{36}$ That disaster indicated impotence of UN in case of human suffering, when the strategic interests of hegemonic powers are not salient.

In Bosnia, Somalia, and Rwanda, there was no peace to keep and even no willingness in making peace. The UN found itself facing with post-Cold war challenges of very different kind, with no peace to keep and humanitarian concerns raising demands for intervention with no clear guidelines on how to proceed. In this environment, the principles of consent, impartiality, and non-use of force except self-defense, which were the basic guidelines for traditional peace keeping operations, seemed inappropriate. All three were civil war situations. The experience of UN forces in each of these theatres highlighted critical issues concerning the contemporary practice of peacekeeping in internal conflicts.

${ }^{36}$ Simons, UN Malaise, p. 101. 


\section{Haiti}

Before 1990, Haiti's history was full of military dictatorships. For a short period in 1990 there was a democratically elected government under President Aristide. Later in that year military rulers took power and expelled Aristide and the other officials. The SC condemned the new rulers and imposed an embargo except for necessary food and medicine. When conditions in the country worsened many people escaped from the country. Consequently, the SC Resolution 940 condemned Haiti for violating human rights. ${ }^{37}$ Then the SC authorized member states to form a UN multinational force with the authority to use all necessary means for ending the military leadership. Thus the Council took a different step in Haiti in treating an internal political crime as a threat to international peace and security. By the help of the US that wanted to avoid the Haitian refugees influx, a multinational UN force was formed and threatened to invade. Then, the UN coalition composed mostly of the US troops occupied Haiti. Soon afterward, President Aristide returned to Haiti and the UN decided to leave a peacekeeping group to keep order until the government came back to power. In 1995, elections were held and President Aristide won. Democratically hold elections, supervised by the UN, at the end of the conflict in Haiti created a positive impression about the UN role in solving an internal dispute. Furthermore, the UN mandate in Haiti assisted to the new government to sustain a secure and stable environment in the country. This case was another example, which shows changes in the UN scope and interest.

\section{Cambodia}

After the end of the Vietnam war, the military government of Cambodia was overthrown and a repressive regime established. The new regime challenged Vietnam in border clashes, and Vietnam responded by invading and establishing a puppet government in Combodia. The new government was supported by the Soviets while China helped the opposition forces. After a bitter civil conflict followed by a decade of occupation by Soviet backed Vietnam, the occupying forces were withdrawn at the end of the

${ }^{37}$ Yoder, Evolution of the UN System, p. 95. 
Cold War. In October 1991, agreements for a comprehensive political settlement of the Cambodia were signed in Paris. Cooperation between the US and the USSR motivated China and Vietnam for supporting a cease-fire in Cambodia.

Then, the UN provided a peacekeeping mission for Cambodia (UNTAC) to implement the agreement and ensure a neutral political environment before the general elections. It also brought together different and complex tasks such as supervising cease-fire, disarming the forces, and the resettlement of refuges in cooperation with the UNHCR. In September 1993, the SecretaryGeneral declared that the UNTAC role in Cambodia ended with the installation of a new constitution and government based on the will of the people expressed through the May 1993 elections. Peacekeepers withdrew and a small group of them stayed for observing and monitoring the peace.

The UN peacekeeping operations in Haiti and Cambodia contributed to the stabilization of peace in both countries. In both cases, there were authoritarian regimes and the missions succeeded in running fair elections. The UN provided complex tasks in these conflicts such as promotion and protection of human rights, organization and giving technical assistance in elections, and repatriation of refugees. As a general evaluation, in Haiti and Cambodia peacekeeping and peace making completed more successfully than in Bosnia and Somalia. The UN supervised elections led to drafting of new constitutions and the establishment of democratic governments by ending long lasting strives.

Beyond the serious questions that have been raised about the ability of the UN to exercise effective command and central of operations that move beyond peacekeeping, the UN confronts enormous challenges in adjusting to newly perceived relations, power and influence. Although some may doubt it, the UN is responding as effectively as possible to current conflicts and humanitarian crises. A more important question involves whether those responses will constitute effective resolutions of the underlying causes of conflict.

The UN found itself facing with very different kinds of postCold war challenges. It had to cope with the conflicts where there was no peace to keep and where humanitarian emergencies made 
the UN intervention unavoidable. The principles of sovereignty, non-intervention into domestic affairs, consent, non-use of force became inappropriate under these circumstances. For example, in the case of Somalia where there was not a legitimate government the concept of sovereignty became meaningless, and the desperate humanitarian situation in Bosnia proved humanitarian intervention inevitable. Under the light of these developments, all the traditional norms of the international relations required reassessment.

\section{Post-Cold War Challenges: Eroding Sovereignty, Non- Intervention, and Humanitarian Intervention}

\section{Eroding National Sovereignty}

Changes in World politics since the end of the Cold War has led to the questioning of the concept of "sovereignty". State sovereignty retains its validity as a defining principle of international society and governing rule in international relations, but the concept has evolved. ${ }^{38}$ Real sovereignty means that national governments control outcomes nationally and internationally. However, in internal wars, where there is not any legitimate government to control events, the principle looses its meaning. The problems inside Rwanda, Somalia, Bosnia, Haiti and Cambodia, though internal problems strictly speaking, were redefined as internal concerns, subject to action by the UN. Therefore, the principle of state sovereignty was defeated by the increasing demand for the effective treatment of internal conflicts by UN.

As former Secretary General Boutros Ghali has noted: "The time of absolute and exclusive sovereignty has passed; its theory was never matched by reality. It is the task of leaders of states today to understood this and find a balance between the needs of good international governance and the requirements of an ever more interdependent world". ${ }^{39}$ As people and states became more interconnected and interdependent, demands increased for international management at the expense of state sovereignty.

38"An Interview with the UN Secretary General Kofi A. Annan", The Fletcher Forum of World Affairs, Vol. 21, No. 2, Summer/Fall 1997.

${ }^{39}$ Ghali, An Agenda for Peace, p. 3. 
While respect for the fundamental sovereignty and integrity of the state remains central, it is undeniable that the centuries old doctrine of absolute and exclusive sovereignty no longer exists as it was considered in the theory.

\section{Non-Intervention}

Consent of the parties for intervention was inevitable for traditional peacekeepers. But opinions are changing on both political and legal necessity of consent of parties. We have lately seen number of examples of intervention into the domestic affairs of states beyond the consent of governments. Intervention is increasingly perceived as legitimate to halt the violence in civil wars that have broken out since the end of the Cold War.

The dynamics of ethnic and religious conflicts as we have seen in Bosnia, Somalia, and Rwanda are very different from the interstate conflicts, which the UN had involved during the Cold War. In previous conflicts reasons of the conflict and the parties were more clearly defined, and when they agreed to a cease-fire, the UN Blue Helmets knew how to operate. However, in ethnic conflicts, reasons of the conflicts and parties are more complex and difficult to identify. In many of these cases, there has not been any legitimate government to obtain consent, nor any effective ceasefire and clear-cut front lines. In such an unstable and anarchic environment, the reliability of sacrosanct principle of consensus is very much reduced as an operational basis for peacekeeping. 40

The experience of the UN in Yugoslavia, Cambodia, Rwanda, Somalia and Haiti clearly demonstrated that within the context of intra-state and ethnic conflicts, strict adherence to the normative principles of consent, impartiality and non-use of force except in self defense substantially reduces the operational efficiency of a peacekeeping force. The most important conclusion that we can drove from these examples is that Article 2(7) i.e., -non-

${ }^{40}$ Charles W. Kegley Jr., Gregory A. Raymond and Margaret G. Hermann, "The Rise and Fall of the Non-intervention Norm: Some Correlates and Political Consequences", The Fletcher Forum of World Affairs, Vol. 22., No. 1, Winter/Spring 1998, p. 89. 
intervention to domestic affairs- became almost meaningless in the post Cold War era.

\section{Humanitarian Intervention}

The challenge to the non-intervention norm is also motivated by humanitarian concerns about the increasing violence and pain in the chaotic environment of the international conflicts. Humanitarian emergencies, by causing the mass exodus of people refugees escaping to neighboring countries- may constitute threats to international peace and security, or aggravate existing threats; conversely, disturbances of peace may give rise to humanitarian crises. ${ }^{41}$

Today, humanitarian assistance has become, an integral part of establishing peace and security in various trouble spots in a way that was never the case before. It aims to not only providing access to the suffering people, but also building bridges between parties in conflict. The basess of this assistance must be humanity, neutrality and impartiality.

The provision of assistance to the victims of war is a difficult task since one party or the other invariably sees humanitarian assistance as a form of external intervention. At the same time, as internal wars came to dominate the statistics of warfare, and the international community seeks to cope with its responsibilities under humanitarian law in these assistance, national sovereignty, and military involvement become intermingled in a complex way. ${ }^{42}$ Combining aid with enforcement on the other hand, raises sensitive issues that call into question the role of humanitarian organizations and the desirability of intervention.

Although the UN broke up all the previous normative principles such as non-intervention and national sovereignty, and intervened to several civil wars in the name of humanitarian

${ }^{41}$ Jan Allison, "Humanitarian Emergencies and the UN", International Affairs, Vol. 4, No. 2, 1994, p. 22.

${ }^{42}$ Tom Woodhouse, Robert Bruce and Malcom Dando, Peacekeeping Peace Making Towards Effective Intervention in Post-Cold War Conflicts, London: MacMillan Press, 1998, p. 49 
assistance, protection of human rights or preventing them to spread neighboring countries and threatening international peace and security, the UN could not be successful entirely. The credibility of the UN seriously damaged in former Yugoslavia, Somalia and Rwanda. It failed to rescue people from desperate circumstances. At the end, suspicion aroused about the impartiality of the peacekeepers, and the UN's legitimacy has weakened.

Beside the loss of confidence in the UN as a security organization, the UN is also experiencing the deepest financial crisis in its history. Many of the SC's decisions on conflict resolution lack either the legal and political strength to make them respected, or the means to implement them in an effective way. ${ }^{43}$ After a brief post-Cold War honeymoon, the UN has once again suffered from the inability to enforce its decisions in critical situations, this time without the excuse of the obstacles created by the Cold War.

The UN has failed in most of its operations after the Cold War, because of the lack of sufficient equipment, resources, and machinery to deal with new kind of conflicts. Existing procedures make it difficult to mobilize peacekeeping contingents and to move them swiftly to operational areas. It is obvious that UN operations in peacekeeping field have to be re-organized.

\section{Organizational Reforms}

Recent developments in the international arena have made the UN reforms inevitable. The UN leadership realized that the Organization needs institutional, managerial, and especially organizational reforms to transform itself into a more effective instrument of international community. Strengthening the role, capacity, effectiveness and efficiency of the UN is necessary to realize the purposes and principles of the Charter, as well as to respond needs of its member states in this era of challenge and expectation.

\footnotetext{
${ }^{43}$ Adam Robers and Benedict Kingsboury, UN in the Divided World, New York: Oxford Univ. Press, 1993, p. 82
} 
The Secretary-Generals' of the UN undertook the leadership for renewing the organization and formed a "program for reform". Beside Boutros Ghali's Agenda for Peace, the present Secretary General Kofi Annan initiated "two track" reform programme for strengthening the Organization. Track One reforms are about managerial reforms within the Secretary General's authority, which can be taken immediately, such as the budget, staff and administration of the UN. ${ }^{44}$ First track reforms made up of ten provisions. These were mainly about the institutional changes to enable the Organization to better carry out its mandates in an increasingly complex world. In addition to the managerial and institutional reforms, the Secretary General in the first track reduced the 1998-1999 budgets for the first time in absolute terms. He believed the current reform efforts could not achieve optimal results unless the Organization's finances are put in order.

The need to put the organization on a sound financial footing is an essential part and a prerequisite to improve the UN's abilities in the future and to accomplish success in proposed reforms. Member states should provide this by paying their full contribution on time without any precondition. One of the most important problems confronting the UN today is coming from here. Although the member countries have a contractual obligation to pay in the Charter, the UN has no effective enforcement tool for compelling them to pay.

Yet, non-payment of assessments is a serious problem for a viability of the UN. There is continuing damage to the credibility of the SC and of the Organization as a whole when the Council adopts decisions that cannot be carried out because the necessary troops are not forthcoming. The heavy demand for UN peacekeeping after Cold War has deteriorated the financial problems of the UN. In the mid-1980s the UN budget crises came to agenda when the US Congress passed legislation designed to cut US contributions. After the Cold War, beside the financial difficulties, increasing peacekeeping expenditures brought the organization to the bridge of bankruptcy. The purpose of the proposals on UN financing is to provide stability and pragmatic consistency in UN operations that based on a steady and

${ }^{44}$ Kofi Annan, Secretary General Details Bold Two-Track Reform Plan, [http://www.un.org/reform/sginit/bgnote.htm], 17 March 1997, p. 1. 
predictable flow of resources for peacekeeping and the range of other activities.

The issues of the Track Two reforms are more fundamental and can be decided only by the member states. It involues a longterm program of reform, and contains complementary measures that reside within the jurisdiction of member states, including the structure and functioning of the Organization. One of them is about the reform of the SC to improve the UN's role in international peace and security after Cold War.

\section{Security Council Reform Proposals}

Charter of the UN gives the SC primary responsibility for the maintenance of international peace and security (Article 24/1). With the ending of the Cold War, the SC has acquired, to a large extend, the role, which was envisaged for it by the architects of the Charter. It is the most powerful organ of the UN. Therefore, the need to reform the UN to strengthen its role in international peace and security naturally focused on the SC. Discussions have mainly focused on size, composition and the decision-making in the SC, including the right of veto.

Many of the criticism of the SC have been about the permanent members of the Council and veto power. There were doubts about preserving, half a century later, the special position of the states, which were allies in World War II. The victors of the WWII, as permanent members, have veto power over substantive issues. The 1963 augmentation of membership from eleven to fifteen did not alter the status of the five permanent members.

Since mid-1960s, UN membership has increased with the decolonization and power relationship have changed in the organization. France and Great Britain are no longer considered as great powers for many people. However, Japan and Germany have gained power by their amount of contribution to the budget of the UN. Middle powers are not satisfied with their position either.

In reflecting the power of the allies that defeated Germany and Japan in 1945 when the UN was founded, it is true that, the Council does not adequately represents the composition of the UN 
members. There are numerous proposals for reform of the SC, with most UN member states having their preferred list of new members and gradations of power. Nevertheless, expanding the SC seems like one of the more reasonable ways to improve the representative character and thus the legitimacy of the world organization in the eyes of its 185 members and their people. ${ }^{45}$ The democratic defects of the Council can be addressed by slightly expanding the SC to reflect current political and economic realities, by reorienting considerations in selecting members, and by diminishing the role of the veto power exercised by the permanent members.

Two main sources of pressure for Council reform, from states in both the industrialized and the developing worlds, emerged in the early 1990s. Both Japan and Germany, who are now among the top four contributors to the UN budget, would like to find a place among the permanent members of the Council. Japan currently contributes more than 12 percent of the budget, while Germany's annual assessed contribution to the UN is considerably larger than either that of France and Britain. ${ }^{46}$ Thus, Japan and Germany have sought permanent seats to reflect their economic powers, supported by the industrialized world especially by the U.S. In June 1993, pursuant to GA Resolution 47/62 of 11 December 1992, the US informed the Secretary General that it "supports permanent membership for Japan and Germany", that it was "also prepared to consider carefully how the Council might be further expanded to include a modest number of additional seats", and that other means of involving non-members of the Council should be explored. ${ }^{47}$

There is however a resistance from the developing world to the proposals giving two more Northern states the same status as the present five. But they have less opportunities to impose their opinions, as a result of greater co-operation among permanent members after the Cold War. Besides, there is a disagreement among them over the form for enlargement. Some developing

${ }^{45}$ Paul Kennedy and Bruce Russet, "Reforming the UN", Foreign Affairs, Vol. 74, No. 5, September/October 1995, p. 60.

${ }^{46} \mathrm{~K}$. P Saksena, Reforming the UN, The Challenge of Relevance, New Delhi: Sage Publications, 1993, p. 182.

${ }^{47}$ Adam Robers, Benedict Kingsboury, Presiding Over a Divided World, New York: Oxford Univ. Press, 1995, p. 53. 
countries, specially the larger aspirant permanent members, have argued that additional Southern permanent seats are vital if the inner circle of existing permanent members is to be influential. ${ }^{48}$ Many small and medium-sized states have challenged the legitimacy of permanent seats and veto, rather than trying to add to their numbers. Instead additional non-permanent seats are sought, with some advocating changes in elections to allow for shared, rotating or de facto permanent seats. ${ }^{49}$ Most developing countries take a pragmatic approach, evaluating the benefit of proposals for permanent and non-permanent expansion.

One of the alternative approaches refers to a criteria that the permanent members together sould include at least half of the world's population, economic productivity, military strength, and contributions to the UN budget. This could be achieved by granting seats automatically to the world's eight most populous countries (China, India, the US, Indonesia, Brazil, Russia, Japan and Pakistan, in descending order) and to its eight most productive economies (the US, Japan, Russia, Germany, France, Italy, the UK, and Canada, in descending order). ${ }^{50}$ According to this project because three countries (the US, Russia, and Japan) are in both groups, this could leave seven or eight other (non-permanent) seats to be elected from among all UN members, assuming an enlarged Council of twenty or twenty-one. All of the existing permanent members are in at least one of the two proposed groups for permanent seats. Therefore, there is no need to leave their seats for this project. But none of the seats under this formula would be absolutely permanent. If the GNP of the ninth place country surpasses the GNP of the country in eighth place over a period of years, it would automatically take a permanent seat.

Weakness of this scheme lie in the fact that people in Africa and the Middle East, divided into less populace states, lack automatic representation of their regions. As a result, another formula developed; any of the five continental regions not otherwise represented in the permanent seats should be automatically represented through a seat reserved for the under-

${ }^{48}$ Sam Daws, 'Seeking Seats, Votes, and Vetoes', The World Today, Vol. 53, No. 10, October 1997, p. 256.

${ }^{49}$ Ibid., p. 256.

${ }^{50}$ Mendlovitz/Weston, Preferred Futures, p. 175. 
represented region from among the elected seats. This reserved seat could be filled through an electoral process, may be with the most populous and influential states, such as Nigeria, South Africa, and Egypt being repeatedly re-elected or selected on a rotating basis. Various proposals like these have been put forward regarding the expansion and the composition of the SC in the proceeding years.

From the developed world point of view, the permanent five have strongly resisted attempts to question their membership and associated rights. In the context of the German candidacy for a permanent place, a European Union seat is sometimes proposed to address Germany's claim to replace both France and the UK. But they strongly resist giving up their veto rights. At this stage, there is no chance to change the existing permanent members of the Council, because they would not vote for their own abolition.

To sum up the ongoing discussion, we can say that while Japan and Germany are obvious industrialized world candidates for new permanent seats, the choice of candidates from Africa, Asia and Latin America is less clear. The main developing world candidates appear as India and Indonesia for Asia; Egypt, South Africa and Nigeria for Africa; and Brazil for Latin America. However, India's candidature has been opposed by Pakistan, Brazil's by the Spanish speaking neighboring states, and Nigeria by a number of states objecting mainly because of the undemocratic nature of the present regime. It is also expected that developing world would not support permanent membership for Japan and Germany without comparable seats for the South.

Regarding Turkey's views on the enlargement of the SC, she suggests the increase of non-permanent membership to 20 by adding 10 new non-permanent members. The new members to the SC should be represented with a rotation system, and a list of countries that can replace the new 10 members should be prepared. Otherwise new constituency groups could be established for the election of the 20 non-permanent members of the SC. Forming new constituency groups according to the geographical positions of the countries is likely to improve the unjust distribution of nonpermanent membership. Turkey believes that the addition of new non-permanent members will increase the representative capacity of the Council. Another important point is that countries, which have more responsibility and weight for the establishment of 
protection of international peace and security, should serve more frequently and regularly on the basis of a rotation system. Of course the fact that Turkey, which is an important regional power constituting a bridge between Europe, Euro-Asia and Middle East, has not gained any representation since 1961, seems to be directing the Turkish authorities to evaluate the matter in this way. ${ }^{51}$

\section{The Veto Power}

The permanent members' veto is a powerful symbol. It has been frequently thought that the veto power of the privileged permanent five is undemocratic. While the veto is surely not democratic, it is the price to keep the big players in the game, where there is no game without them.

The veto privileges of five states nevertheless provoke contention, and it is widely perceived as having held the UN back from fulfilling its functions during the Cold War. Yet, the veto has merits as well as faults; it helped to get and keep the major powers within the UN framework when they would otherwise have either not joined in the first place or else deserted it; it may saved the UN from damaging conflicts with its major members; it has contributed to a sense of responsibility and a habit of careful consultation among the permanent five; and it reduces the risk of acute discrepancies between power politics and the law of the UN Charter. ${ }^{52}$ In short, the veto can be viewed as one of several factors, which have made for the superiority of UN's decision-making procedures over those of its predecessor, the League of Nations, and over many other regional organizations.

The issue of veto remains a sticking point in the reform proposals. Some countries believe that the new permanent members should possess equal rights -as does the means of determining who should be the new members. At the same time granting a veto to new permanent members proved unacceptable to many countries, while others argued that withholding the veto for

\footnotetext{
51 A Publication by the Turkish Foreign Ministry.

52 Stephen Schlesinger, 'Can the UN Reform', World Policy Journal, Fall 1997, p. 49.
} 
these new members would create a new category of membership still inferior in power and in standing to the original permanent five. ${ }^{53}$ Some countries wished to address the issue of the perceived "reverse" veto under which any of the permanent five could prevent the modification of certain open-ended sanctions regime by threatening to veto any proposed changes.

After the end of the Cold War, growing co-operation in the peacekeeping and peace enforcement operations led to the questioning of the necessity of veto. For many people, in a world where co-operation was possible, and national troop contributions to UN military operations is voluntary, the reasons behind the veto bucame less obvious, and giving this right to new members getting harder to justify.

Since increasing the number of permanent members with the veto faces opposition and abolition of veto is unlikely, there are proposals to restrict the veto for existing and new permanent members. These include limiting the range of areas in which the veto can be used, allowing its use only when an item affects a permanent member's "supreme national interests", instituting a system of weighted voting that would allow the Council to override a veto, and increasing the total number of negative votes needed to veto a resolution. ${ }^{54}$ One of the proposals, for example, argued that the new permanent members sould not have the right to veto, a right that a majority of countries hope would eventually become obsolete. In addition, the proposal urged the original permanent members to limit the use of veto to Chapter VII of the Charter, which deals with the Council's enforcement powers.

\section{Conclusion}

The UN has entered into a process of transformation with the end of the Cold War. A new hope arose that the UN system could be renewed to function properly. Furthermore, co-operation in the SC to stop Iraq's aggression against Kuwait reinforced the hopes for the UN's future role. A widespread optimism among the

${ }^{53}$ David M. Malone,' The UN Security Council in the Post Cold War World: 1987-97', Security Dialogue, Vol. 28, No. 4, 1997, p. 402.

${ }^{54}$ Weiss/Forsythe/Coate, The UN and Changing World Politics, p. 94. 
scholars, the politicians, the media and in the public appeared for a revitalized UN at the end of the Cold War.

Therefore, a sense of euphoria surrounded the UN. Thus, the SC called on the Secretary-General Ghali to prepare a programme of reform on ways of strengthening and making the UN more efficient within the framework of the Charter. The Secretary General in his "An Agenda for Peace" defined novel concepts such as preventive diplomacy, peacemaking and post-conflict peace building to support UN's peacekeeping operations. However, the new kind of internal conflicts that exploded soon after the end of the Cold War showed that "An Agenda for Peace" failed to touch on the challenging concepts of non-intervention and state sovereignty.

The years after the end of the Cold War witnessed the outbreak of many internal wars in different parts of the world as in the former Yugoslavia, Rwanda, Haiti, Cambodia and Somalia. The Gulf War became the last case of the traditional interstate wars. In the contemporary world, the nature of conflict have been changing and the UN called on to deal with these new kinds of armed conflicts which could not be predicted when the UN Charter was drafted. Since the Charter was designed for interstate conflicts and the Organization was not equipped to deal with conflicts within internal borders, the UN could not be successful in overcoming these conflicts, as it was expected.

While handling these conflicts, the UN had to break traditional principles and norms such as non-use of force in peacekeeping operations, non-intervention into domestic affairs and state sovereignty. Further, the SC authorized to undertake enforcement action to create conditions for humanitarian relief operations, and defense of the UN personnel in Bosnia, Somalia, and Rwanda. This blurred the distinction between the peacekeeping and peace enforcement operations of the UN. Although this arrangement improved the UN's efficiency, it also created a negative impact on the Organization's credibility.

Since the end of the Cold War, while the old patterns of interaction have broken down or changed significantly, new patterns have not yet crystallized. Prior ways to solve the problems are not sufficient any more, and they are under challenge, but the 
new ones have not yet emerged. Although the member states are dissatisfied with the past experiences of the UN, they have not yet obtained the necessary political will for a new UN to manage world politics after the Cold War.

Under these circumstances, it seems clear that the UN was designed for a world that is over now. The spirit that created the UN to prevent the repetition of another world war is not alive today. Hence, the UN is ill-equipped to respond adequately to the crises of present. As a result, the UN needs reforms to perform its function as it was designed in the Charter. Without reform, it will lack both the credibility and capacity to meet the challenges of the contemporary world.

Still, the ability of the UN to meet adequately the demands of present and future world conditions depends on the policies of its member states. The UN can only do what the member states wish it to do. As an inter-governmental organization, its reforms heavily depends on the member states, especially to the more powerful ones. Thus, the sole remaining superpower US policies for political, military and financial reasons would mainly determine the main parameters of the UN's future operations. We have seen in cases of Somalia, Haiti and Yugoslavia that the US support for UN peacekeeping is worthwhile. In addition, NATO's co-operation with the UN for providing necessary military power was useful in Bosnia. Since Chapter eight of the UN Charter allows it to cooperate with the regional organizations, there was no problem in this co-operation. However, NATO is a collective defense organization and its logic is different from the UN's peacekeeping operations. Thus, problems occurred in the Bosnian operations with NATO. However, the UN and NATO would need to cooperate in future operations as well, simply because UN needs NATO's equipment and resources while NATO needs to attend UN peacekeeping operations in order to justify its existence and relevance after the dissolution of the Soviet Union.

However, as the conflicts grew worldwide, the troopcontributing countries, even the US, are becoming increasingly reluctant to commit personnel to UN operations. The failure of UN in Somalia, Bosnia, and Rwanda had a negative impact on their willingness, too. Clearly, it is extremely difficult for any government to justify why its own nationals should die in conflicts 
that the public does not understand and where a compelling political interest cannot be demonstrated. Therefore, it is important to materialize the discussed proposals of An Agenda for Peace, about preventive diplomacy, peacemaking, peacebuilding and budgetary issues to keep alive the UN operations in future. It became visible to put more UN resources into preventive strategies, and to find new and improved sources for funding UN's peace and security activities.

Nevertheless, none of the reform proposals should be done in an incremental fashion in response to immediate emergencies or persistent and often misguided public criticism of the organization. Instead, it must reflect a long-term plan aimed at giving the UN the ability, when and if the political will exists, to respond quickly to future requests for peacekeeping involvement. An Agenda for Peace is a good first step towards dealing with the new environment in the area of peace and security by using the potential enshrined in the Charter to a greater extent than before. The priority given to preventive diplomacy and other preventive approaches in the Secretary General's "Supplement to An Agenda for Peace", and the recognition of the need to draw clear distinctions between different types of responses, especially between peace keeping and enforcement, is welcome suggestions as well.

Moreover, there was a general agreement among the member states, in the light of the mistakes of the UN in internal wars, that basic principles of peacekeeping which are; the consent of the parties, impartiality and non-use of force except in self defense, should be obsorved in future. Especially Third World countries stressed that UN peacekeeping operations should adhere strictly to the principles and purposes of the Charter, in particular the principles of respect for sovereign equality and territorial integrity of states and non-interference in their internal affairs. ${ }^{55}$

Furthermore, reforming the UN to expand its role in international politics brought the SC on the agenda as well. Since the Charter of the UN gives the Council a primary responsibility

${ }^{55}$ Abderahman S. Abderahman, Comprehensive Review of the Whole Question on Peacekeeping Operations,. A/50/230, gopher.un.org, 22 June 1995, p. 4. 
for the maintenance of international peace and security, its reform regarded as unavoidable. Reform proposals, to put the SC at the center of future international peace and security matters, focuses on the size, composition and the decision making of the Council. Although the member states of the UN reached a consensus that the number of both permanent and non-permanent members of the SC should be increased, and the privilege of veto power should be abolished to have a more democratic and better functioning Council, there was lack of consensus about how to proceed with the reforms. However, if the UN desires to be an important instrument of international politics, it is essential to find ways to reform the Council.

At this point, the UN should strive continuously to improve its capabilities according to new circumstances and changes in the world agenda. Its future success depends on creating new ways to overcome prospective crises. The changed face of conflict today requires us to be perceptive, adaptive, creative, and courageous, and to address simultaneously the immediate as well as the root causes of conflict, which all too often lie in the absence of economic opportunities and social inequalities. 